\title{
SIFAT MEKANIK PIPA KOMPOSIT SERAT GELAS, KARBON DAN KARBON KEVLAR YANG DIBUAT DENGAN METODE BLADDER COMPRESSION MOLDING
}

\section{Ubazu Amirudin dan Gesang Nugroho}

Universitas Gadjah Mada (UGM) Yogyakarta, Indonesia

Email: bayuamir456@gmail.com dan gesangnugroho71@mail.ugm.ac.id

\begin{tabular}{l}
\hline INFO ARTIKEL \\
\hline Diterima \\
15 Februari 2021 \\
Direvisi \\
20 Februari 2021 \\
Disetujui \\
15 Maret 2021
\end{tabular}

Keywords:

bladder compression molding; composite pipe; mechanical properties

\begin{abstract}
The increasing use of composite pipes for various purposes such as in offshore industries where high corrosion resistance, high rigidity to weight ratio and low maintenance costs are critical. This study aims to investigate the mechanical properties of composite pipes using bladder compression molding method at 7 bar pressure and $120^{\circ} \mathrm{C}$ temperature and room temperature. Tensile test results showed that carbon fiber composite pipes, kevlar carbon and glass with natural curing process had the highest strength with tensile strength of 375, 281 and $156 \mathrm{MPa}$ respectively. While the highest bending strength in carbon fiber composite pipes, carbon kevlar and glass with curing process $120^{\circ} \mathrm{C}$ with strong bending of 268, 131 and $85 \mathrm{MPa}$ respectively. The highest stiffness values in carbon fiber composite pipes, kevlar carbon and glass with curing process $120^{\circ} \mathrm{C}$ with values of 46, 25 and $18 \mathrm{KPa}$ respectively. Tensile test results showed that carbon fiber composite pipes, kevlar carbon and glass with natural curing process had the highest strength with tensile strength of 375, 281 and 156 $M P a$ respectively. While the highest bending strength in carbon fiber composite pipes, carbon kevlar and glass with curing process $120^{\circ} \mathrm{C}$ with strong bending of 268, 131 and $85 \mathrm{MPa}$ respectively. The highest stiffness values in carbon fiber composite pipes, kevlar carbon and glass with curing process $120^{\circ} \mathrm{C}$ with values of 46,25 and 18 $\mathrm{KPa}$ respectively. This shows that the bladder compression molding method used in this study has better mechanical properties than AM (addictive manufacturing), VARTM and compression molding methods.
\end{abstract}

\section{ABSTRAK}

Meningkatnya penggunaan pipa komposit untuk berbagai keperluan seperti pada industri lepas pantai di mana 


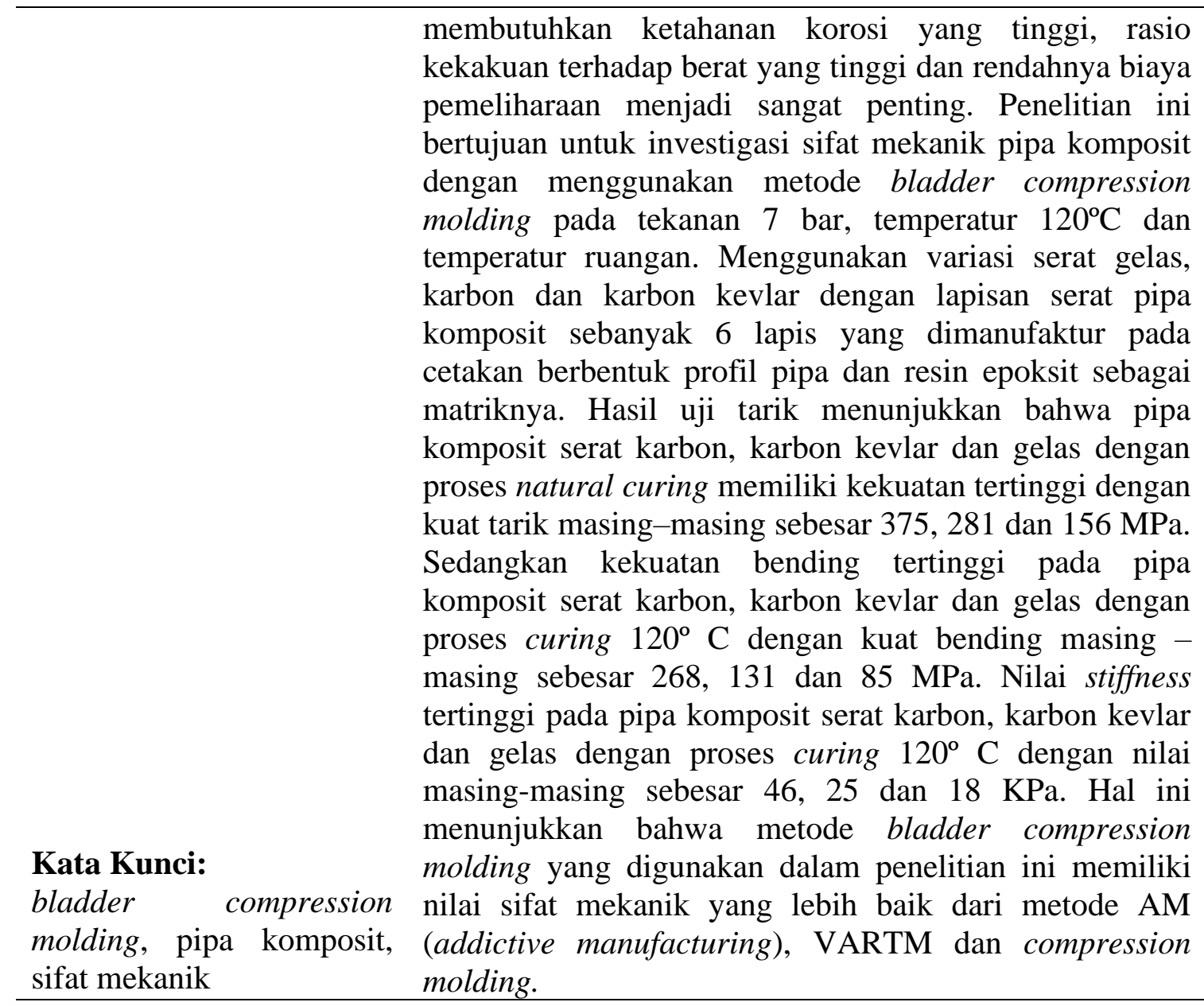

Coresponden Author

Email: bayuamir456@gmail.com

Artikel dengan akses terbuka dibawah lisensi

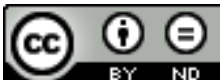

\section{Pendahuluan}

Pemanfaatan material komposit akhir-akhir ini semakin banyak dan luas pada komposit bergeometri komplek salah satunya adalah pada pipa komposit. Meningkatnya penggunaan pipa komposit untuk berbagai keperluan seperti pada industri lepas pantai di mana membutuhkan ketahanan korosi yang tinggi, rasio kekakuan terhadap berat yang tinggi dan rendahnya biaya pemeliharaan sangat penting. Beberapa peneliti telah melakukan penelitian tentang pipa komposit terutama tentang proses manufakturnya (Dell'Anna et al., 2018). Kekuatan struktur dari pipa komposit ditentukan dari proses manufaktur. Sehingga pemilihan proses manufaktur menjadi hal yang utama agar didapat produk pipa komposit yang seamless, kuat dan ringan. Ovalization dimulai lebih cepat dalam tabung yang seamless sebagai akibat dari kurangnya circumferential stiffness (Fard et al, 2019). Secara umum, proses manufaktur pipa komposit dilakukan dengan menggunakan metode pultrusion dan filament winding 
Pada umumnya berbagai keperluan struktural seperti sifat mekanik dari polimer tidak seperti yang diharapkan, kekakuan dan rigidnya sangat rendah dibandingkan dengan logam dan keramik (Karthik et al, 2020). Pada manufaktur komposit berongga bisa dilakukan menggunakan metode handlay-up. Metode ini merupakan metode yang paling mudah tetapi produk yang dihasilkan memiliki sifat mekanik yang rendah. Selanjutnya dikembangkan dengan metode handlay-up dan vacum-bagging. Dengan metode tersebut bisa membuat suatu produk komposit dengan bentuk yang komplek serta dapat meminimalkan kandungan void serta menghasilkan fraksi volume yang tinggi, akan tetapi metode ini masih memiliki kelemahan yaitu hasil cetakannya masih terbagi menjadi dua, dan pada proses selanjutnya masih harus dilakukan penyambungan pada kedua bagian tersebut. Sehingga adanya sambungan dari produk komposit menimbulkan masalah baru yang menyebabkan luasan pada komposit berongga menjadi tidak uniform serta tidak seamless yang akan berpengaruh pada kekuatan struktur pipa komposit tersebut. Selain proses di atas kemudian dikembangkan proses manufaktur filament winding. Proses manufaktur filament winding mampu menghasilkan produk tanpa sambungan dan kepadatan serat yang tinggi. Proses manufaktur ini juga dapat menghasilkan orientasi dan keseragaman serat yang baik. Namun proses manufaktur filament winding ini memerlukan biaya yang tidak sedikit, selain itu tidak dapat membuat produk komposit dengan bentuk yang kompleks. Untuk mengatasi permasalahan di atas, cetakan bladder dapat digunakan untuk membuat komponen komposit berongga atau hollow. Bladder compressioon molding merupakan metode dalam pembuatan komposit yang menggunakan bladder sebagai alat penekan pada serat dan campuran resin. Tekanan internal diberikan pada elemen elastis. Kemudian tekanan bahan komposit pada dinding cetakan terjadi. Cetakan dipanaskan melalui pemanas yang tertanam.

(Antameng, 2020) melakukan penelitian tentang "desain cetakan yang efektif dalam konsumsi energi untuk manufaktur produk hollow composite dengan metode bladder compression molding". Hasil penelitian tersebut menunjukkan bahwa karakteristik perpindahan panas lebih merata dan konsumsi energi lebih efektif dengan menggunakan desain pemanas di dalam molding. Namun penelitian yang dilakukan oleh (Antameng, 2020) masih terdapat kekurangan yaitu, belum dilakukan lebih lanjut terkait investigasi sifat mekanik. Sehingga pada penelitian ini akan berfokus pada investigasi sifat mekanik pada pipa komposit yang dibuat dengan metode bladder compression molding yang membandingkan proses pembuatan pipa komposit menggunakan pemanas inside molding dan tanpa menggunakan pemanas (room temperatur) dengan menggunakan material serat yang berbeda yaitu serat karbon, karbon kevlar dan gelas. Investigasi sifat mekanik pada penelitian diantaranya adalah tensile dan compressive mechanical test dilakukan pada bagian-bagian dari produk komposit berrongga atau hollow untuk mendapatkan sifat mekanik aksial dan circumferential (Toh et al., 2018).

(Eggers et al., 2019) meneliti tentang respon mekanis cincin komposit yang bertujuan untuk mengevaluasi pengaruh dari winding angle, susunan lapisan dan rasio 
diameter terhadap ketebalan pada respon mekanis cincin komposit yang mengalami kompresi radial, kompresi aksial dan beban tarik melingkar. Cincin komposit tersebut di buat dengan menggunakan metode filament winding. Hasil yang diperoleh bahwa cincin komposit ditemukan sangat tergantung pada winding angle, misalnya spesimen dengan serat pada $\pm 90^{\circ}$ mendapatkan karakteristik kompresi radial terbaik, sedangkan pada serat $\pm 60^{\circ}$ dilakukan dengan baik di bawah kompresi aksial, dan kekuatan tarik melingkar ditentukan melalui pengujian split disk lebih tinggi untuk cincin komposit di $\pm 90^{\circ}$. Semua cincin komposit tergantung pada rasio diameter terhadap ketebalan. Kegagalan dianalisa melalui mikrograf spesimen post-mortem. Mode kegagalan dominan untuk kompresi radial, kompresi aksial dan beban tarik melingkar secara masing-masing adalah delaminasi, delaminasi dan retakan kecil dari sumbu, dan debonding serat/matriks dan kerusakan serat.

(Wang et al., 2016) melakukan penelitian tentang optimalisasi proses infusion resin untuk key-part pipa komposit dan sambungan tipe k/t menggunakan metode vacuum-assisted resin transfer molding (VARTM). Dalam penelitian ini. Pola aliran depan dan waktu pengisian percobaan menunjukkan kecocokan yang baik dengan simulasi. Gambar cross-section pipa komposit yang dikeringkan dan bagian sambungan tipe $\mathrm{K} / \mathrm{T}$ membuktikan validitas proses injeksi yang dioptimalkan, yang memverifikasi efisiensi metode simulasi dalam memperoleh proses injeksi VARTM yang sesuai.

(Schillfahrt., 2017) melakukan penelitian tentang pengaruh proses tekanan pada perilaku mengisi fabrics berbentuk tabung dengan metode pembentukan bladderassisted resin transfer molding (BARTM). Metode ini memungkinkan efisien pembuatan bagian komposit berongga berdasarkan pada tekstil penguat berbentuk tabung. Penelitian ini mempelajari perilaku impregnasi pada biaxial braided fabric di dalam tekanan dorong BARTM di bawah berbagai injeksi dan tekanan bladder. Percobaan saturasi dilakukan dengan menggunakan uji rig injeksi yang dikembangkan secara khusus yang terdiri dari bladder elastomer under-sized dan cetakan transparan monolitik. Hasil yang diperoleh menunjukkan pengaruh signifikan dari parameter proses yang relevan pada pemadatan preform lokal, permeabilitas global yang nyata, dan waktu pengisian. Berdasarkan percobaan, diagram universal moldability telah diturunkan yang memungkinkan identifikasi kondisi operasi yang kritis dan dapat diterima dalam BARTM, yang mendukung penemuan pengaturan pengisian bagian yang optimal.

(Ismadi, 2019) telah melakukan penelitian tentang pengaruh tekanan terhadap sifat mekanik pada manufaktur komposit serat karbon/epoxy dengan metode bladder compression moulding (BCM). Penelitian ini bertujuan mencari efek perubahan tekanan pada bladder di mulai dari komposit formasi dengan tekanan bladder 1, 2, 3, 4, 5, 6, 7 dan 8 bar. Spesimen uji diperoleh dengan memotong setiap produk komposit menggunakan mesin router cnc. Selanjutnya komposit diuji secara mekanik, yaitu uji tarik dan uji bending. Selain itu uji fisik juga dilakukan uji densitas. Dari hasil penelitian menunjukkan bahwa kekuatan tarik tertinggi dicapai pada tekanan bladder 7 bar, dengan fraksi volume serat 65,87 dan densitasnya 1,64. Sementara kekuatan lentur 
tertinggi dicapai pada tekanan bladder 8 bar. Kekuatan dan densitas produk komposit meningkat sementara porositas menurun, seiring dengan peningkatan tekanan pada bladder.

(Setyoko, 2019) melakukan penelitian tentang pengaruh temperatur curing terhadap sifat mekanik pada manufaktur komposit serat karbon/epoksi dengan metode pembentukan bladder compression moulding (BCM). Pembentukan komposit dengan metode BCM dilaksanakan pada tekanan tetap sebesar 5 bar dan waktu pemanasan selama 60 menit. Temperatur yang digunakan adalah temperatur ruang, $60^{\circ}, 80^{\circ}, 100^{\circ}$, $120^{\circ}, 140^{\circ}$ dan $190^{\circ} \mathrm{C}$. Hasilnya menunjukkan bahwa penelitian ini telah mengembangkan sistem dan perangkat dalam pembentukan komposit dengan metode $\mathrm{BCM}$, dari data yang diperoleh bahwa kekuatan tarik dan kekuatan bending tertinggi diperoleh dari proses pada temperatur curing $12 \mathrm{M} 0^{\circ} \mathrm{C}$. Pada proses temperatur curing $120^{\circ} \mathrm{C}$ ini juga dihasilkan nilai densitas bahan dan fraksi volume serat terbesar sementara porositas yang dihasilkan adalah minimal.

(Putra, 2020) melakukan penelitian yang bertujuan untuk memperoleh waktu optimum pada manufaktur komposit dengan metode bladder compression moulding serta mempelajari pengaruh variasi waktu curing terhadap sifat mekanis produk komposit yang dihasilkan pada tekanan 7 Bar dan temperatur $120^{\circ} \mathrm{C}$ dan pada temperatur ruangan. Sebanyak 6 lapis serat karbon dan 6 lapis serat gelas dibentuk dalam sebuah cetakan dan resin epoxy sebagai matriksnya dengan variasi waktu penahanan pada $10,20,30,40,50,60,70$ menit serta $8,10,12$ dan 14 jam pada temperatur ruangan. Hasil uji tarik menunjukkan bahwa kekuatan tarik tertinggi komposit epoksi/serat karbon yaitu pada waktu tahan 40 menit (351MPa) dan $316 \mathrm{MPa}$ pada waktu tahan 14 jam. Kekuatan tarik tertinggi komposit epoksi/serat gelas diperoleh pada waktu tahan 30 menit (279 MPa) dan $269 \mathrm{MPa}$ pada waktu tahan 10 jam. Kekuatan bending tertinggi material komposit epoksi/serat karbon yang dibentuk menggunakan sistem pemanas $120^{\circ} \mathrm{C}$ diperoleh pada waktu tahan 40 menit ( $99 \mathrm{MPa}$ ) dan pada room temperature diperoleh pada waktu 14 jam (68.2 MPa) sedangkan pada material komposit epoksi/serat gelas menggunakan sistem pemanas $120^{\circ} \mathrm{C}$ kekuatan bending tertinggi diperoleh pada waktu tahan 30 menit (50.5 MPa) dan waktu tahan 12 jam (49.4 $\mathrm{MPa}$ ) pada pembentukan dengan room temperature.

(Kechout., 2019) telah melakukan penelitian tentang analisis tegangan sisa dalam tabung komposit multilayer yang digunakan untuk pembawa air minum. Tegangan sisa telah diukur dengan menggunakan teknik crampton dan metode penghilangan lapisan. Pengamatan menunjukkan bahwa tekanan tegangan sisa bekerja melalui $80 \%$ ketebalan dinding tabung. Oleh karena itu, keberadaan lapisan pusat GFP memungkinkan untuk menyeimbangkan distribusi tegangan selama masa kerja tabung. Distribusi tegangan sisa sesuai dengan persetujuan evolusi energi yang diserap secara mekanis per satuan volume bahan sesuai dengan lokasinya di dalam tabung induk. Untuk sebuah diameter dan ketebalan pipa ekuivalen, tegangan sisa pada pipa komposit sepuluh kali lebih tinggi dari pada pipa PE. 
(Taktak., 2017) telah meneliti tentang Pengaruh serat E-glass dan orientasi lapisan pada perlakuan mekanis komposit FRP yang digunakan untuk pipa tekanan. Tujuan utama dari penyelidikan eksperimental ini adalah untuk membandingkan perilaku mekanik resin yang diperkuat dengan woven fabrics yang berbeda (bidirectional dan quadriaxial rovings) yang dibuat dengan metode hand lay-up. Dari hasil utama, itu ditemukan bahwa komposit berdasarkan kain R500 menunjukkan perilaku terbaik dalam uji tarik sedangkan laminasi berdasarkan kain RM menunjukkan sifat lentur terbaik. laminasi komposit quadriaxial (QA/VE dan QA/UP) dengan urutan susun dari $\left[0^{\circ},+45^{\circ}, 90^{\circ},-45^{\circ}\right]$ memberikan perilaku daya tarik yang sangat elastis dan resistensi fraktur interlaminar tertinggi.

(Xu et al., 2016) melakukan penelitian tentang crashworthiness tabung komposit serat karbon. Dalam penelitian ini, lima jenis tabung komposit yang dibuat dengan metode filament winding dan kinerja crashworthiness diselidiki secara eksperimental. Efek dari crushing speed, temperature treatment, bahan baku dan struktur termasuk rasio hibrida, orientasi serat dan ketebalan dinding tabung pada kemampuan penyerapan energi diselidiki melalui tes kompresi quasi-statis dan kompresi dinamis. Pengamatan mikroskop optik dari penampang dilakukan untuk menganalisis mekanisme kegagalan. Tabung FRP karbon/aramid hibrida setelah temperature treatment menunjukkan bahwa Es tertinggi dalam uji quasi-statis (Rata-rata $98 \mathrm{~kJ} / \mathrm{kg}$ ) dan tes dinamis (rata-rata 82 $\mathrm{kJ} / \mathrm{kg}$ ) yang memiliki pengelolaan penyerapan energi sangat baik.

\section{Metode Penelitian}

Pada penelitian ini proses pembuatan produk komposit hollow menggunakan metode bladder compression modling dengan cetakan dari alumunium dan profil cetakan dalam berbentuk pipa, di dalam cetakan terdapat sebuah bladder untuk menampung udara bertekanan tinggi dari kompresor. Pada setiap bagian cetakan terdapat dua elemen pemanas yang ditanam di dalam setiap cetakan, di mana temperatur diatur oleh thermo control. Dapat dilihat pada gambar 1 skema set-up pembuatan produk komposit hollow. 


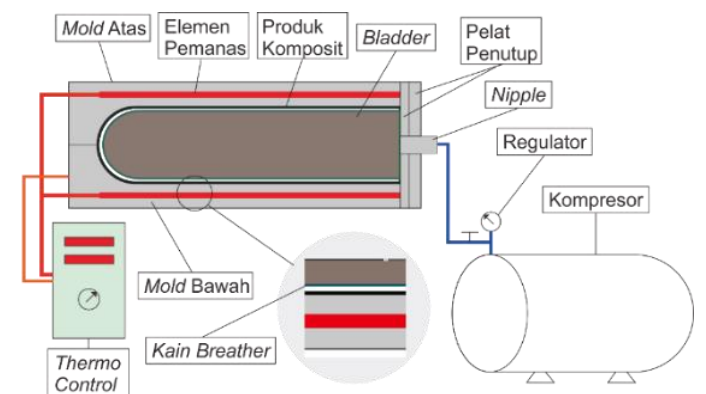

a)

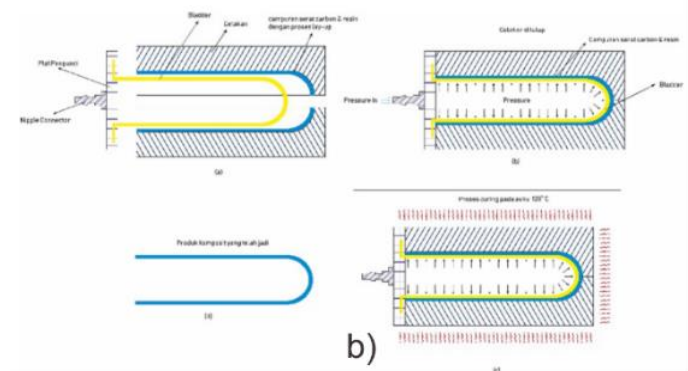

Gambar 1

a). Skema Set Up Bladder Compression Molding Produk Komposit Hollow, B) Skema Pembuatan Produk Komposit Hollow

Penelitian ini menggunakan variasi material yaitu serat gelas, karbon dan karbon kevlar dengan dua proses curing yang berbeda. Pertama variasi serat akan di manufaktur dengan menggunakan pemanas dengan temperatur $120^{\circ} \mathrm{C}$ selama 40 menit. Kedua, variasi material akan di manufaktur dengan tanpa pemanas selama 14 jam dengan tekanan konstan 7 bar. Bladder digunakan untuk memperbesar area penekanan pada komposit sedangkan pemanas (heater) digunakan untuk mempercepat proses curing. Bladder terbuat dari bahan silicone rubber, sedangkan untuk matriknya menggunakan resin dengan jenis epoksi resin tipe Bisphenol A Epichlorohydrin dengan hardener jenis EPH 555 Cycloaliphatic Anime dengan perbandingan resin dan hardener 1:1. Releaser mirror glaze digunakan sebagai lapisan cetakan molding komposit, sehingga produk komposit yang telah dibuat dapat dengan mudah dilepas dari cetakan. Pada penelitian ini digunakan kain breather dan perforated parting film yang berfungsi sebagai lapisan penyerap resin dan pelindung bladder dari kebocoran yang diakibatkan oleh serat yang telah mengeras.

Tabel 1

Komposisi Material

\begin{tabular}{cccc}
\hline Material & Temperatur $\left({ }^{\mathbf{C}} \mathbf{C}\right)$ & Tekanan (bar) & $\begin{array}{c}\text { Lama Proses Curing } \\
\text { (menit) }\end{array}$ \\
\hline Carbon fiber & Natural curing & 7 & 14 jam \\
\hline Carbon Kevlar & Natural curing & 7 & 14 jam \\
\hline Glass & Natural curing & 7 & 14 jam \\
\hline Carbon fiber & $120^{\circ}$ & 7 & 40 menit \\
\hline Carbon Kevlar & $120^{\circ}$ & 7 & 40 menit \\
\hline Glass & $120^{\circ}$ & 7 & 40 menit \\
\hline
\end{tabular}


Setiap variasi pembentukan komposit hollow menghasilkan produk komposit hollow yang kemudian dipotong untuk mendapatkan bentuk spesimen sesuai standar uji. Berikut ini contoh spesimen uji yang telah dipotong dengan menggunakan cnc router.
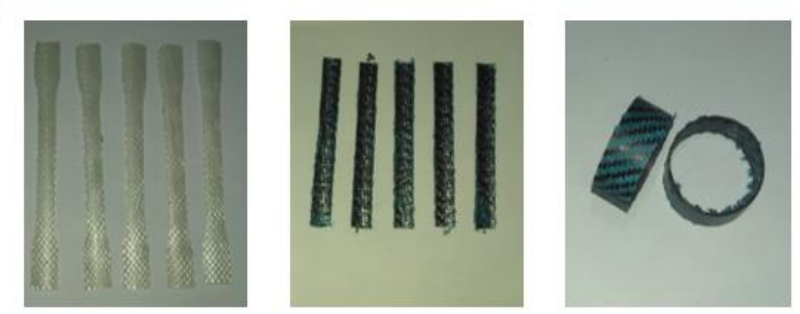

\section{Gambar 2 \\ Spesimen Pengujian}

Produk komposit hollow yang merupakan hasil dari proses manufaktur dengan metode bladder compression molding selanjutnya dilakukan pemeriksaan sifat-sifat mekaniknya melalui pengujian Tarik ASTM D638, pengujian bending ASTM D790 dan pengujian ring stiffness BS EN 1228.

\section{Hasil dan Pembahasan}

Pada penelitian ini metode bladder compression molding digunakan untuk menghasilkan produk komposit berbentuk hollow dari material gelas/epoksi, karbon/epoksi dan karbon kevlar/epoksi. Kemudian produk komposit hollow dipotong dengan menggunakan mesin cncn router untuk mendapatkan bentuk spesimen yang sesuai dengan standar pengujian mekanik. Jenis pengujian mekanik yang dilakukan adalah pengujian tarik, pengujian bending, dan pengujian ring stiffness untuk mengetahui kekuatan material komposit hollow.

Pengujian tarik dilakukan sesuai dengan standar ASTM D638, hasil pengujian tarik (tensile test) material epoksi/serat gelas, epoksi/serat karbon dan epoksi/serat karbon. Kevlar ditampilkan dengan bentuk grafik perbandingan sifat mekanik berikut. 


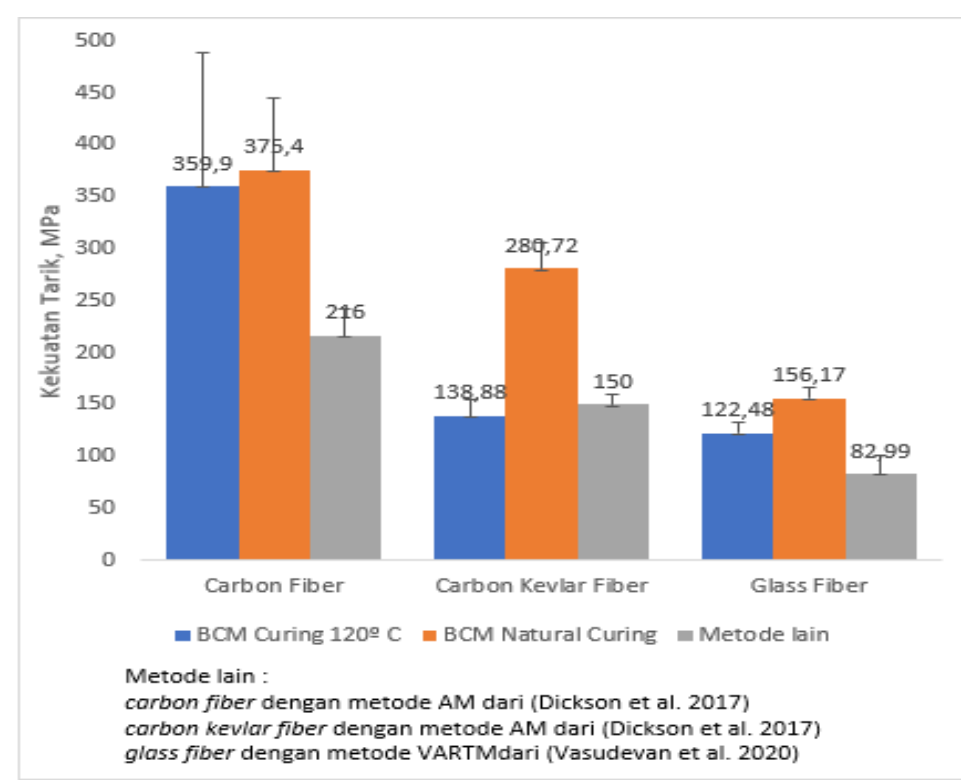

\section{Gambar 3}

\section{Kekuatan Tarik Komposit Epoksi/Serat Gelass, Epoksi/Serat Karbon dan Epoksi/Serat Karbon Kevlar}

Gambar 3 menunjukkan kekuatan tarik komposit, epoksi/serat karbon, epoksi/serat karbon kevlar dan epoksi/serat gelas dengan tiga proses pembuatan yang berbeda. Kekuatan tarik tertinggi dengan komposit epoksi/serat karbon, epoksi/serat karbon kevlar dan epoksi/serat gelas ditemukan pada proses pembuatan dengan menggunakan natural curing dengan nilai masing-masing yaitu 375,4, 280,72 dan 156,17 MPa. Sedangkan kekuatan tarik pada metode lain dengan material karbon, karbon kevlar dan gelas yaitu dari (Dickson et al 2017), (Vasudevan et al., 2020) memiliki nilai masing-masing sebesar 216, 150 dan $83 \mathrm{MPa}$.

Fenomena ini disebabkan dengan semakin banyaknya kandungan serat di dalam pipa komposit yang dibuat dengan proses natural curing, maka kontribusi serat sebagai penahan beban juga akan semakin besar. Hal ini tentu saja didukung oleh adanya ikatan yang baik antara serat dan matrik. Pada saat pembebanan berlangsung, beban terdistribusi secara merata pada seluruh permukaan serat sehingga serat menanggung beban yang sama.

Sedangkan untuk modulus tarik pipa komposit serat gelas, karbon dan karbon kevlar dengan proses natural curing memiliki nilai tertinggi. Hal ini dapat diamati pada gambar berikut ini. 


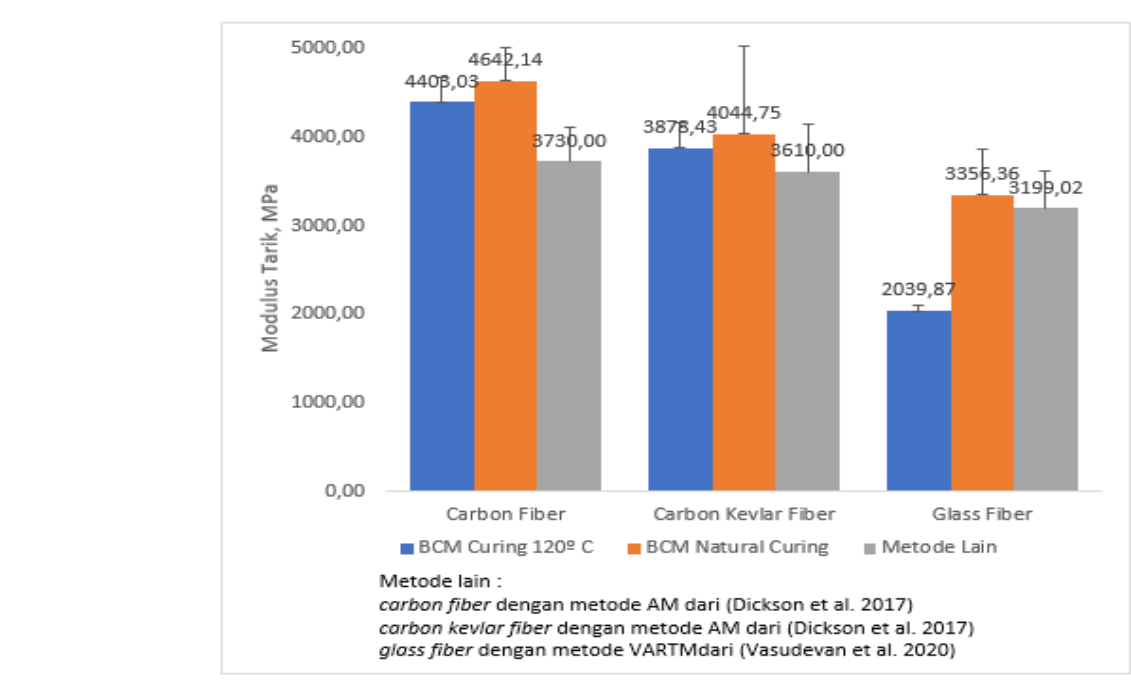

\section{Gambar 4 \\ Modulus Tarik Komposit Epoksi/Serat Gelass, Epoksi/Serat Karbon dan Epoksi/Serat Karbon Kevlar pada Pengujian Tarik}

Gambar 4 menunjukkan kekuatan modulus komposit, epoksi/serat karbon, epoksi/serat karbon kevlar dan epoksi/serat gelas dengan tiga proses pembuatan yang berbeda. Kekuatan modulus tertinggi dengan komposit epoksi/serat karbon, epoksi/serat karbon kevlar dan epoksi/serat gelas ditemukan pada proses pembuatan, BCM natural curing, BCM natural curing dan BCM natural curing dengan nilai masing - masing yaitu 4600, 4000 dan 3350 Mpa. (Elkazaz et al., 2020) Jelas bahwa modulus elastisitas sangat dipengaruhi oleh fraksi volume serat. Hal ini pada pipa komposit yang dibuat dengan metode natural curing memiliki fraksi volume yang lebih tinggi dibandingkan dengan proses curing menggunakan pemanas.

Sedangkan modulus tarik pada metode lain dengan material karbon, karbon kevlar dan gelas yaitu dari (Dickson et al 2017), (Vasudevan et al., 2020) memiliki nilai masing-masing sebesar 3730, 3610 dan $3199 \mathrm{MPa}$.

Peningkatan modulus tarik menunjukkan bahwa proses curing mempengaruhi terhadap kandungan fraksi volume. Pada gambar di atas menunjukkan bahwa proses natural curing memiliki nilai modulus yang lebih tinggi dibandingkan dengan proses curing dengan sistem pemanas, hal ini disebabkan karena pada proses natural curing memiliki nilai fraksi volume yang tinggi dibanding dengan proses curing sistem pemanas.

Pengujian bending empat titik dilakukan sesuai dengan standart ASTM D790. Hasil pengujian bending empat titik material epoksi/serat gelas, epoksi/serat karbon dan epoksi/serat karbon kevlar ditampilkan dengan bentuk grafik. 


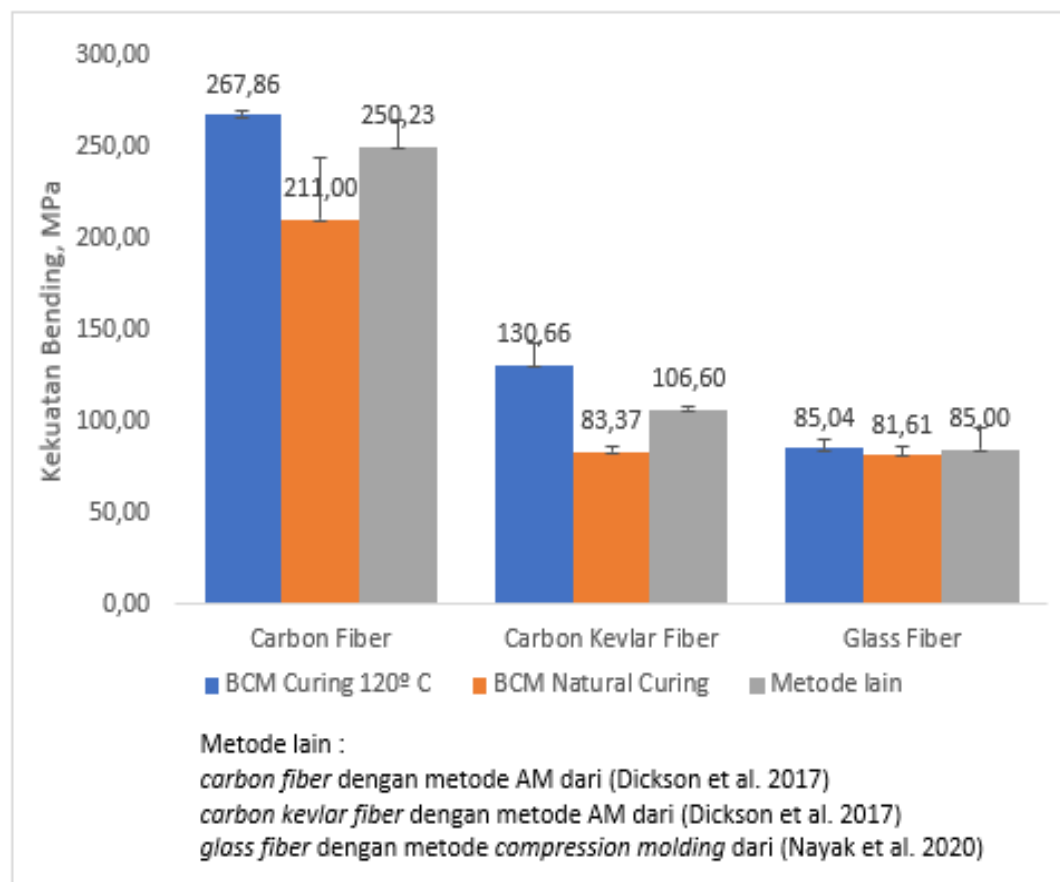

\section{Gambar 5}

\section{Kekuatan Bending Komposit Epoksi/Serat Gelas, Epoksi/Serat Karbon dan Epoksi/Serat Karbon Kevlar pada Pengujian Bending Empat Titik}

Gambar 5 menunjukkan kekuatan bending komposit pada sampel komposit epoksi/serat karbon $120^{\circ} \mathrm{C}$, epoksi/serat karbon natural curing, epoksi/serat karbon kevlar $120^{\circ} \mathrm{C}$, epoksi/serat karbon kevlar natural curing, epoksi/serat gelas $120^{\circ} \mathrm{C}$, epoksi/serat gelas natural curing dan metode lain. Kekuatan bending tertinggi dengan komposit epoksi/serat karbon $\mathrm{BCM}$ curing $120^{\circ} \mathrm{C}$, epoksi/serat karbon kevlar BCM curing $120^{\circ} \mathrm{C}$ dan epoksi/serat gelas $\mathrm{BCM}$ curing $120^{\circ} \mathrm{C}$ dengan nilai masing-masing yaitu 267,86, 130,66 dan 85,04 Mpa. Sedangkan kekuatan bending pada metode lain dengan material karbon, karbon kevlar dan gelas yaitu dari (Dickson et al 2017), (Nayak et al., 2020) memiliki nilai masing-masing sebesar 250,106 dan $85 \mathrm{MPa}$.

Peningkatan kekuatan bending yang terjadi pada pipa komposit serat gelas, karbon dan karbon kevlar dengan proses curing $120^{\circ} \mathrm{C}$. Hal ini erat kaitannya dengan ketebalan pipa komposit, di mana ketebalan pipa komposit dengan proses curing sistem pemanas mengalami penambahan ketebalan sedangkan pada pipa komposit dengan proses natural curing mengalami penurunan ketebalan. Sedangkan untuk modulus bending, pipa komposit serat gelas, karbon dan karbon kevlar juga mengalami peningkatan dengan proses curing $120^{\circ} \mathrm{C}$. Seperti yang terlihat pada gambar 6 di bawah ini. 


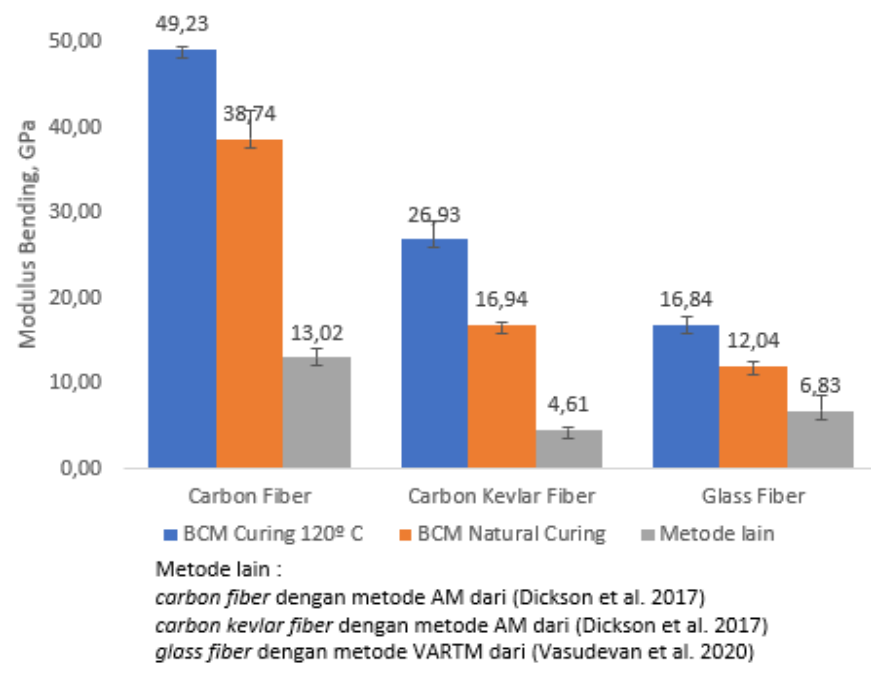

\section{Gambar 6}

\section{Modulus Bending Komposit Epoksi/Serat Gelass, Epoksi/Serat Karbon dan Epoksi/Serat Karbon Kevlar pada Pengujian Bending Empat Titik}

Gambar 6 menunjukkan kekuatan modulus sampel komposit epoksi/serat karbon $120^{\circ} \mathrm{C}$, epoksi/serat karbon natural curing, epoksi/serat karbon kevlar $120^{\circ} \mathrm{C}$, epoksi/serat karbon kevlar natural curing, epoksi/serat gelas $120^{\circ} \mathrm{C}$, epoksi/serat gelas natural curing dan metode lain. Kekuatan modulus tertinggi dengan komposit epoksi/serat karbon curing $120^{\circ} \mathrm{C}$, epoksi/serat karbon kevlar $120^{\circ} \mathrm{C}$, dan epoksi/serat gelas $120^{\circ} \mathrm{C}$, dengan nilai masing-masing yaitu 49,23, 26,93 dan 16,84 GPa. Sedangkan modulus bending pada metode lain dengan material karbon, karbon kevlar dan gelas yaitu dari (Dickson et al 2017), (Vasudevan et al., 2020) memiliki nilai masing-masing sebesar 13,5 dan $7 \mathrm{GPa}$. Peningkatan modulus bending yang terjadi pada pipa komposit dengan proses curing $120^{\circ} \mathrm{C}$ menunjukkan bahwa seiring dengan kenaikan ketebalan pipa komposit, maka pipa komposit juga akan semakin kaku. Sifat kaku dipengaruhi oleh regangan maksimum yang dihasilkan (Elkazaz et al., 2020). Jelas bahwa modulus elastisitas sangat dipengaruhi oleh fraksi volume serat. Hal ini pada pipa komposit yang di buat dengan metode natural curing memiliki fraksi volume yang lebih tinggi dibandingkan dengan proses curing menggunakan pemanas.

Pengujian ring stiffness dilakukan sesuai dengan standart BS EN 1228. Hasil pengujian ring stiffness pada komposit epoksi/serat gelas, epoksi/serat karbon dan epoksi/serat karbon kevlar ditampilkan dengan bentuk grafik. Seperti yang terlihat pada gambar 7 grafik perbandingan nilai kekakuan. 


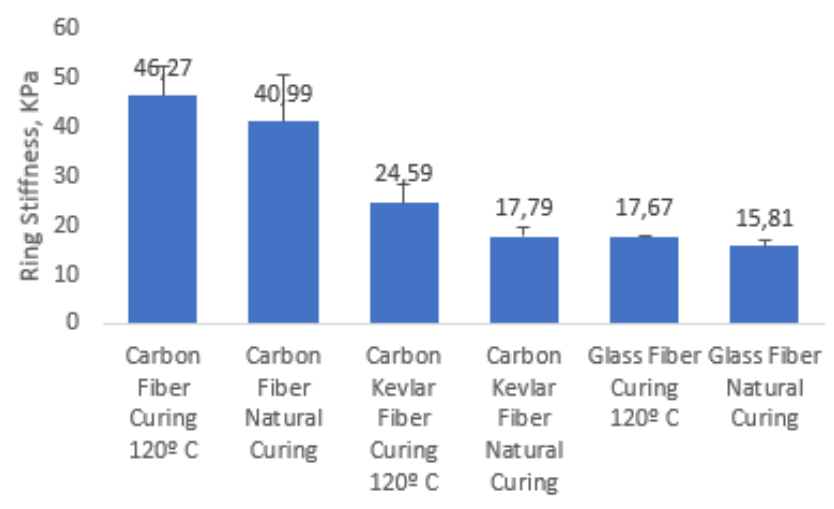

\section{Gambar 7 \\ Ring Stiffness Komposit Epoksi/Serat Gelas, Epoksi/Serat Karbon dan Epoksi/Serat Karbon Kevlar pada Pengujian Ring Stiffness}

Gambar 7 menunjukkan tingkat kekakuan pada sampel komposit epoksi/serat karbon $120^{\circ} \mathrm{C}$, epoksi/serat karbon natural curing, epoksi/serat karbon kevlar $120^{\circ} \mathrm{C}$, epoksi/serat karbon kevlar natural curing, epoksi/serat gelas $120^{\circ} \mathrm{C}$, epoksi/serat gelas natural curing. Kekakuan tertinggi terjadi pada serat karbon curing $120^{\circ} \mathrm{C}$, karbon kevlar curing $120^{\circ} \mathrm{C}$ dan gelas curing $120^{\circ} \mathrm{C}$ dengan nilai masing-masing yaitu 46,25 dan $18 \mathrm{KPa}$. Sedangkan kekakuan terendah terjadi pada pipa komposit serat gelas, karbon dan karbon kevlar dengan menggunakan natural curing. Hal ini erat kaitannya dengan ketebalan pipa komposit, di mana ketebalan pipa komposit dengan proses curing sistem pemanas mengalami penambahan ketebalan sedangkan pada pipa komposit dengan proses natural curing mengalami penurunan ketebalan.

\section{Kesimpulan}

Metode bladder compression molding untuk produksi pembuatan pipa komposit menggunakan serat glass, carbon dan carbon kevlar telah disajikan. Diketahui bahwa metode pembuatan dengan Kekuatan tarik tertinggi material komposit adalah pada pipa komposit serat karbon, karbon kevlar dan gelas dengan proses natural curing dengan kuat tarik masing-masing sebesar 375,281 dan $156 \mathrm{MPa}$. Sedangkan kekuatan bending tertinggi pada pipa komposit serat karbon, karbon kevlar dan gelas dengan proses curing $120^{\circ} \mathrm{C}$ dengan kuat tarik masing-masing sebesar 268,131 dan $85 \mathrm{MPa}$. Nilai stiffness tertinggi pada pipa komposit serat karbon, karbon kevlar dan gelas dengan proses curing $120^{\circ} \mathrm{C}$ dengan nilai masing-masing sebesar 46, 25 dan $18 \mathrm{KPa}$. Hal ini menunjukkan bahwa metode bladder compression molding yang digunakan dalam penelitian ini memiliki nilai sifat mekanik yang lebih baik dari metode AM (addictive manufacturing), VARTM dan compression molding. 
Sifat Mekanik Pipa Komposit Serat Gelas, Karbon dan Karbon Kevlar yang Di Buat dengan Metode Bladder Compression Molding

\section{BIBLIOGRAFI}

Antameng, Budi Purwanto. (2020). Desain Cetakan Yang Efektif Dalam Konsumsi Energi Untuk Manufaktur Produk Hollow Composite Dengan Metode Bladder Compression Molding Effective (Vol. 5). Universitas Gadjah Mada Yogyakarta.

Dell'anna, Riccardo, Lionetto, Francesca, Montagna, Francesco, \& Maffezzoli, Alfonso. (2018). Lay-Up And Consolidation Of A Composite Pipe By In Situ Ultrasonicwelding Of A Thermoplastic Matrix Composite Tape. Materials, 11(5).

Dickson, Andrew N., Barry, James N., Mcdonnell, Kevin A., \& Dowling, Denis P. (2017). Fabrication Of Continuous Carbon, Glass And Kevlar Fibre Reinforced Polymer Composites Using Additive Manufacturing. additive manufacturing, 16(june), 146-152.

Eggers, Frederico, Almeida, José Humberto S., Azevedo, Cristiano B., \& Amico, Sandro C. (2019). Mechanical Response Of Filament Wound Composite Rings Under Tension And Compression. Polymer Testing, 78(January). Https://Doi.Org/10.1016/J.Polymertesting.2019.105951

Elkazaz, E., Crosby, W. A., Ollick, A. M., \& Elhadary, M. (2020). Effect of fiber volume fraction on the mechanical properties of randomly oriented glass fiber reinforced polyurethane elastomer with crosshead speeds. Alexandria Engineering Journal, 59(1), 209-216.

Ismadi, Ignatius Henry. (2019). Pengaruh Tekanan Terhadap Sifat Mekanik Pada Manufaktur Komposit Serat Karbon/Epoxy Dengan Metoda Bladder Compression Moulding. Universitas Gadjah Mada.

Karthik, K., Rajamani, D., Manimaran, A., \& Udayaprakash, J. (2020). Evaluation of Tensile Properties on Glass/Carbon/Kevlar Fiber Reinforced Hybrid Composites. Materials Today: Proceedings, (Xxxx).

Kechout, K., Amirat, A., \& Zeghib, N. (2019). Residual stress analyses in multilayer $\mathrm{pp} / \mathrm{gfp} / \mathrm{pp}$ composite tube. International Journal Of Advanced Manufacturing Technology, 103(9-12), 4221-4231.

Nayak, Suhas Yeshwant, Satish, Shenoy B., Sultan, Mohamed Thariq Hameed, Kini, Chandrakant R., Rajath Shenoy, K., Samant, Rashmi, Sarvade, Praneeth P., Basri, Adi Azriff, \& Mustapha, Faizal. (2020). Influence of fabric orientation and compression factor on the mechanical properties of $3 \mathrm{~d}$ e-glass reinforced epoxy composites. Journal Of Materials Research And Technology, 9(4), 8517-8527.

Putra, Muhammad Idris. (2020). Pengaruh Curing Time Terhadap Sifat Mekanis Pada Pembentukan Komposit Epoxy/Carbon Fiber Dan Epoxy/Glass Fiber Dengan 
M. Ubazu Amirudin dan Gesang Nugroho

Metode Bladder Compression Molding (Vol. 28). Universitas Gadjah Mada.

Schillfahrt, Christian, Fauster, Ewald, \& Schledjewski, Ralf. (2017). Influence Of process pressures on filling behavior of tubular fabrics in bladder-assisted resin transfer molding. Advanced Manufacturing: Polymer And Composites Science, $3(4), 148-158$.

Setyoko, Antonius Dwi. (2019). Pengaruh Temperatur Curing Terhadap Sifat Mekanik Pada Manufaktur Komposit Serat Karbon/Epoksi Dengan Metoda Pembentukan Bladder Compression Moulding. Universitas Gadjah Mada.

Taktak, Rym, Guermazi, Noamen, \& Kossentini Kallel, Tasnim. (2017). Effect of Eglass fibre and ply orientation on the mechanical behaviour of frp composites used for pressure pipe. International Journal Of Advanced Manufacturing Technology, 92(5-8), 1741-1749.

Toh, William, Tan, Long Bin, Tse, Kwong Ming, Giam, Anthoni, Raju, Karthikayen, Lee, Heow Pueh, \& Tan, Vincent Chye. (2018). Material characterization of fi lament-wound composite pipes. Composite Structures Journal, 206(July), 474483.

Vasudevan, A., Navin Kumar, B., Victor Depoures, Melvin, Maridurai, T., \& Mohanavel, V. (2020). Tensile And Flexural Behaviour Of Glass Fibre Reinforced Plastic - Aluminium Hybrid Laminate Manufactured By Vacuum Resin Transfer Moulding Technique (Vartm). Materials Today: Proceedings, $(X x x x)$.

Wang, Changchun, Bai, Guanghui, Yue, Guangquan, Wang, Zhuxi, Li, Jin, \& Zhang, Boming. (2016). Optimization Of Resin Infusion Processing For Composite Pipe Key-Part And K/T Type Joints Using Vacuum-Assisted Resin Transfer Molding. Applied Composite Materials, 23(5), 1065-1078.

Xu, Jing, Ma, Yan, Zhang, Qianjin, Sugahara, Toshi, Yang, Yuqiu, \& Hamada, Hiroyuki. (2016). Crashworthiness Of Carbon Fiber Hybrid Composite Tubes Molded By Filament Winding. Composite Structures, 139, 130-140.

Yekani Fard, Masoud, Raji, Brian, Woodward, John, \& Padilla, Michael. (2019). Experimental Characterization Of Damage Mechanisms Of Seamless NetShaped Circular Pre-Form And Overlapped Stitched Composite Pipes. Polymer Testing, 78(March). 